\title{
A Review on the Use of Azolla Species in Poultry Production
}

\author{
Wafaa A. Abd El-Ghany \\ Poultry Diseases Department, Faculty of Veterinary Medicine, Cairo University, 1211, Giza, Egypt
}

Corresponding author's E-mail: wafaa.ghany@yahoo.com; ORCID: 0000-0003-1686-3831

Received: 04 Apr. 2020

Accepted: 19 May 2020

\begin{abstract}
Aquatic plants are receiving a lot of attention in nutrition research, which is due to their broad range of uses in animal and human food. Azolla is one of the commonly used these floating plants. Currently, different Azolla species are used as maintainable feed alternatives for cattle, pigs, poultry, and fish as dried flakes or fresh form. In addition to high protein and essential amino acid content of Azolla, the fern is rich in other nutrients such as minerals, vitamins, and pigments. There is a discrepancy in the use of Azolla to improve the productivity of poultry. However, most studies have indicated that the incorporation of broiler ration with certain levels of Azolla promotes feed intake, body weight gain, feed conversion rate, and general health conditions as Azolla comprises growth promoters. In layers, the use of Azolla improves productivity in terms of egg quantity and quality as Azolla contains pigments, minerals, and essential amino acids. Moreover, Azollas improves carcass traits at processing. Therefore, this review article provides information on Azolla plant, its composition, and the significance of its supplementation for different poultry species.
\end{abstract}

Key words: Azolla, Broilers, Immunity, Layers, Performance

\section{INTRODUCTION}

As a result of declining food resources around the world and increasing their costs, the search for unconventional resources for poultry production has become increasingly important. In addition, there is a serious effort to replace the conventional feed ingredients of poultry ration with cheap items to reduce the costs. Aquatic plant species do not appear to accumulate secondary plant compounds due to their growth habits and therefore offer greater potential than tree leaves as a source of protein for monogastric animals (Bacerra et al., 1995; Wagner, 1997). Several studies had been done on the nutritive value of aquatic plant Azolla. Azolla is a small aquatic and floating fern of the family Azollaceae and the order Pteridophyta. The name is referred to azo (to dry) and allyo (to kill) as the fern can be killed after exposure to drought conditions. In the world, at least eight species of Azolla are known, namely Azolla pinnata, Azolla nilotica, Azolla caroliniana, Azolla japonica, Azolla circinata, Azolla microphylla, Azolla rubra, and Azolla Mexicana, of which most common is Azolla pinnata (Mathur et al., 2013). Azolla is an abundantly available aquatic fern in the stagnant water of ponds, drains, rivers, canals, marshy fields and wetland paddy in tropical and subtropical countries of the world. This fern can be cultivated under natural and controlled environmental conditions (Senthilkumar and Manivannam, 2016). The blue-green symbiotic cyanobacterial partner alga (Anabaena azollae) grows in Azolla leaves cavities (Becking, 1979). Azolla, in turn, provides carbon source, nutrients, and a protective cavity to Anabaena colonies in exchange for fixed high amount of atmospheric dinitrogen as well as growth promoters (Pillai et al., 2005). This special symbiotic relationship makes Azolla a great and protein-rich plant (Mooventhan et al., 2019).

Azolla was originally used as green manure but is now used as mosquito inhibitor, herbicide, water saver and purifier, fertilizer saver (Van Hove and Lejeune, 1996), cough medicine (Raja et al., 2012), saline soils reclaimer (Raja et al., 2012), biogas producer (Van Hove, 1989; Das et al., 1994) and bioremediator (Sood et al., 2012; Yadav et al., 2014). Azolla fern is promising in terms of the ease of cultivation, the minimal water for propagation, the rapid biomass production, the growth in unexploited niches, productivity and nutritive value (Singh and Subudhi, 1978; Lumpkin and Plucknett, 1982; Van Hove and Lejeune, 1996; Pillai et al., 2002; Alalade and Iyayi, 2006; Prabina and Kumar, 2010). It is reported that the addition of Azolla 
in rations significantly reduces the feed cost (Escobin, 1987; Bacerra et al., 1995; Lawas et al., 1998; Sujatha et al., 2013). The bio-composition of Azolla makes it one of the cheapest, economic, potential, efficient, and maintainable feed alternatives for livestock and poultry (Pannaerker, 1988; Kathirvelan et al., 2015).

Azolla pinnata meal has long been used successfully for broiler and layer chickens (Castillo et al., 1981; Querubin et al., 1986; Bhuyan et al., 1988; Sreemannarayana et al., 1993; Basak et al., 2002; Alalade and Iyayi, 2006; Balaji et al., 2009; Dhumal et al., 2009; Naghshi et al., 2014), ducks (Escobin, 1987; Bacerra et al., 1995; Lawas et al., 1998; Sujatha et al., 2013; Acharya et al., 2015), quails (Rathod et al., 2013; Shamna et al., 2013; Varadharajan et al., 2019), fish (Nwanna and Falaye, 1997) and rabbits (Wittouck et al., 1992; Sreemannarayana et al., 1993; Sadek et al., 2010; Anitha et al., 2016a). Moreover, dietary Azolla pinnata has been applied for feeding of shrimps, goats, cattle and buffalo calves (Sudaryono, 2006; Hossiny et al., 2008; Indira et al., 2009; Mandal et al., 2012; Rawat et al., 2015), while Azolla filiculoides has been added to diets of sows as protein source replacer (Leterme et al., 2010) and for growing fattening pigs (Bacerra et al., 1995).

Therefore, this review article provides an overview of Azolla plant composition and the significance of its supplementation for different poultry species.

\section{Composition of Azolla}

Azolla is a rich and potential source of protein (2535\%), nitrogen (Lumpkin, 1984), almost all essential amino acids (7-10\%) especially lysine (Van Hove, 1989), essential minerals such as iron, calcium, phosphorous, magnesium, manganese, potassium, iron and copper (1015\%), vitamins like vitamin A and vitamin B12 (Bacerra et al., 1995; Lejeunea et al., 1999), carotenoids, chlorophyll a and $\mathrm{b}$, bio-polymers, probiotics, and growthpromoting intermediates (Ivan and Thuget, 1989; Tamany et al., 1992; Lejeune et al., 2000; Pillai et al., 2005; Alalade and Lyayi, 2006; Lakshmi and Sailaja, 2012; Mathur et al., 2013; Parashuramulu et al., 2013; Cherryl et al., 2014; Henry et al., 2017). Thus, Azolla is considered a significant source of nutrients. Furthermore, cyanobiont of Anabaena azollae contains chlorophyll a, phycobiliproteins, and carotenoids (Tyagi et al., 1980). However, its contents of carbohydrate and oil are low. Azolla is highly digestible because of lignin and high protein contents (Anitha et al., 2016b). A study by Namra et al. (2010) revealed the presence of high levels of energy in Azolla which is important for both digestion and availability of nutrients. Azolla appears to be a possible biofertilizer due to nitrogen contribution to rice crops (Kannaiyan, 1992).

\section{Effects of Azolla supplementation on production performance \\ Broiler chickens}

The addition of Azolla to the poultry diet economizes production. Azolla is a cheap and plentiful alternative plant protein source that improves FCR, energy efficiency, and performance with no adverse effects on livestock, poultry, and humans (Lejeunea et al., 1999; Alalade and Lyayi, 2006; Namra et al., 2010). Although there are inconsistent results, the majority of the data show enhancement of production and reproduction of livestock and poultry fed with diet containing Azolla.

Many studies have demonstrated the efficiency of using Azolla at different replacement concentrations in the ration of broiler chickens. However, Ali and Leeson (1995) found that feeding of broilers on Azolla resulted in similar body weight and growth like those kept on a maize-soybean meal. Also, Sarria and Preston (1995) found an increase in the growth of broilers when soybean protein was replaced by Azolla up to $15 \%$ level. Sundararaju et al. (1995) investigated the performance modulating effects of dietary Azolla, Sesbania, and Leucaena proteins on broilers and found that the addition of them to broiler chicken diet at a level of $6 \%$ significantly improved the body weight at 4,6 and 8 weeks of age. Improvement in the FCR as a result of Azolla feeding was also reported by Ardakani et al. (1996). Seth et al. (2013) found an increase in efficiency at 5-15\% Azolla level in the ration of broilers, while Balaji et al. (2009, 2010); Namra et al. (2010); Ara and Adil (2012); Sujatha et al. (2013); and Naghshi et al. (2014) found this improvement at 5\% level. Incorporation of Azolla up to $5 \%$ as a feed ingredient to replace sesame meal in the ration of 2 to 6-week-old broilers improved growth rate, FCR, and energy efficiency without deleterious effect on palatability and mortalities (Basak et al., 2002), along with promising economic returns (Parthasarathy et al., 2002). The use of $20 \%$ fresh Azolla was suggested as a substitute for commercial feed in chicken diets as it could increase the body weight (Subudhi and Singh, 1978). A significant difference in the feed intake was observed when Azolla increased up to $15 \%$ in the diet (Querubin et al., 1986). The study by Dhumal et al. (2009) demonstrated a significant increase in feed intake with an increase in Azolla levels up to 30\%. However, Bacerra et al. (1995) indicated a benefit from Azolla supplementation at a low 
level of inclusion. Similarly, Ara et al. (2015) found a linear reduction in feed intake with increasing Azolla levels in the diets of broiler chickens. It was found that Azolla pinnata meal can be safely included up to $15 \%$ in growing pullet ration with no health issues (Alalade et al., 2007) but $10 \%$ inclusion level in pullet chick diet has given the best performance. Incorporation of the concentrate feed with Azolla at $7.5 \%$ level resulted in an increase in the body weight up to $2.6 \%(1.99 \mathrm{~kg})$ compared to control diet $(1.93 \mathrm{~kg})$. In addition, the consumed feed was lower in broilers fed on $7.5 \%$ Azolla (Prabina and Kumar, 2010). Seth et al. (2013) also detected increased weight gain in Vanaraja chicken fed on $5 \%$ or $10 \%$ Azolla over control. Saikia et al. (2014) demonstrated that the highest body weight gain was in the group supplemented with 5\% Azolla while the lower one was in the group fed with $15 \%$ level and they explained that increasing the fiber content in high concentrations of Azolla negatively affects the appetite of the birds and consequently reduces the growth rate. They also concluded that Azolla can be added to the broiler diet by $10 \%$ level without adverse effect in the performance. Improvement in body weight gain as well as FCR was detected after the inclusion of Azolla at $5 \%$ or $10 \%$ level in the feed (Acharya et al., 2015) and up to $7.5 \%$ level (Kumar et al., 2018). Moreover, the feed cost of production was considerably reduced by the inclusion of Azolla at either level. The inclusion of Azolla at $10 \%$ level showed the maximum economic benefit. A study carried out by Henry et al. (2017) indicated that fresh Azolla supplementation (30 $\mathrm{g} / \mathrm{bird} / \mathrm{day})$ reduced feed consumption with no effects on growth performance parameters in 7-week-old turkeys, which might be due to high protein level and mineral content of Azolla. The addition of dried Azolla to Vencobb broilers ration can be used safely up to 5\% without any adverse effects, however, 2.5\% addition level of Azolla is effective in improving both growth and biochemical parameters (Rana et al., 2017). It was revealed that inoculation of Azolla at levels of $5 \%$ or $7 \%$ is appropriate for safe and profitable production of broilers due to reduced FCR, mortalities, and production costs, as well as improved net profit (Islam and Nishibor, 2017). The addition of Azolla to the basal ration could improve FCR with no adverse effects on blood biochemistry and immune parameters (Shukla et al., 2018). Recently, Samad et al. (2020) suggested that the addition of Azolla up to 15\% level enhances the growth performance traits without negative effects on the nutrient digestibility of broiler chickens.
On the other side, some researchers found no or low effects of Azolla supplementation on poultry production performance. Higher levels compared to low levels of aquatic plants result in lower body weight, which may be related to the high level of neutral detergent fiber (Buckingham et al., 1978) and tannin contents (Tamany et al., 1992) as limiting factors for FCR as well as efficient nutrient utilization (Muzlar et al., 1978). The decrease in the consumed feed may be due to reduced palatability (Bested and Morento, 1985) and increased bulkiness of Azolla (Bacerra et al., 1995) which reduces its utilization. Castillo et al. (1981), Bhuyan et al. (1988), and Sreemannarayana et al. (1993) found that inclusion of Azolla by $15 \%$ in broilers ration did not affect feed consumption. The discrepancy in the trend of feed intake could be attributed to the differences in the nutrient composition of the diets and Azolla species used. Moreover, another study on Azolla revealed a proportional decrease in the body weights of broilers (Parthasarathy et al., 2002). The results of Biplob et al. (2002) and Balaji et al. (2009) indicated no changes in the production performance of broiler chickens after feeding on Azolla compared to control. In addition, Alalade and Iyayi (2006) attributed the lower growth rate of broilers fed on high levels of Azolla to the lower feed intake and subsequently the reduction of metabolizable energy intake. Alalade et al. (2007) demonstrated that addition Azolla to the ration of pullets up to $10 \%$ level induced non-significant differences in growth parameters.

Limited researches have been conducted on evaluating the effects of Azolla supplementation on the carcass traits. Higher dressing percentage of broiler chicken with giblet percentage at $15 \%$ was reported in the treatment group fed on 5\% Azolla (Basak et al., 2002) and this improvement was attributed to the higher body weight gains. Feeding on 5\% Azolla powder significantly increased the carcass yield percentages of broiler chicks, while lowest percentage was observed in $15 \%$ Azolla supplemented group (Naghshi et al., 2014) However, Ara et al. (2015) found no adverse effect on carcass traits on feeding Azolla up to $20 \%$ level.

\section{Ducks}

Some studies also showed the effects of Azolla as a supplement in the ration of ducks. Azolla as an unconventional nutrient source could be added by $10 \%$ to the basal diet of white Pekin broiler ducks (Acharya et al., 2015). In the study of Escobin (1987), the author found no differences in the production efficacy among different groups after partial replacement of growing Muscovy ducks ration with Azolla at levels of 20,30, and 40\%. In 
addition, 15\% replacement of soybean meal with Azolla increased the daily weight gains of ducks (Bacerra et al., 1995), however, at levels 20, 45, or $60 \%$ of Azolla, the growth rate was reduced. Similar findings on the production performance of ducks were reported (Lawas et al., 1998; Sujatha et al., 2013). In the same line, Lawas et al. (1998) observed that feeding of Mallard ducks with Azolla at levels of 75 or $250 \mathrm{~g} / \mathrm{bird} /$ day lowered the FCR. In a trial with ducks, Bacerra et al. (1995) demonstrated that by addition of 15 to $60 \%$ Azolla in diet supplying $15.2-30.3 \%$ of the total protein, the FCR decreased with increasing Azolla consumption. However, studies with long periods are needed to determine the effect of Azolla supplementation on performance at older ages.

\section{Quails}

Shamna et al. (2013) reported that feeding of quails on Azolla at 5\% replacement level of the basal ration enhanced the growth and FCR, also it was more economic than feeding on basal diet alone. Varadharajan et al. (2019) concluded that Azolla meal up to 6\% can include in quails diet without affecting feed consumption and carcass traits. Rathod et al. (2013) reported non-significant effects of Azolla supplementation on feed consumption of Japanese quails.

\section{Layer chickens}

The pigmenting ability of group fed with Azolla was demonstrated by its higher Roche fan color score and this could be attributed to the ability of Azolla to pigment the yolk as it is rich in $\beta$ carotene pigment. A similar effect on yolk color due to the inclusion of Azolla in layer ration was reported by Bastian (1987). Ali and Leeson (1995) found that the addition of Azolla powder to chicken feed significantly improved the carotene status of the chicken and increased egg production. Moreover, Khatun et al. (1999) investigated the replacement of sesame oil in the ration of layers by Azolla $200 \mathrm{~g} / \mathrm{kg}$ and reported good egg mass output and FCR. A similar better egg production performance was detected by Kannaiyan and Kumar (2005) in terms of higher egg yield after Azolla inclusion at the level of $100 \mathrm{~g} / \mathrm{bird} /$ day. Lakshmanan et al. (2017) stated supplementation of Azolla in layers diets resulted in increasing egg production, improving the nutrient value as well as saving the concentrated feed. The positive effect of Azolla on eggshell strength was referred to the high calcium content of Azolla. It has been found that the eggshell consists of minerals especially calcium carbonate that deposits in the organic matrix (Austic and Nesheim, 1990). It was reported that inoculation of Azolla in the ration of layer chickens at levels up to $20 \%$ had no effect on alanine aminotransferase and aspartate aminotransferase levels, which indicates no toxic effect of Azolla cristata supplementation (Ara et al., 2018).

\section{Effects of Azolla supplementation on immunity}

Prabina and Kumar (2010) demonstrated higher values of antibody titer against the Ranikhet virus in broilers fed on $10 \%$ dried Azolla in comparison with those received $7.5 \%$ dried Azolla. The authors explained increased immunity in Azolla treated birds by the ability of the fern to assimilate atmospheric dinitrogen through algal symbionts (Anabaena) in its leaves. The immunemodulatory effect of Azolla meal without any toxicity was detected by Mishra et al. (2016) as birds treated with 5\%, $7.5 \%$, and $10 \%$ Azolla showed higher cell-mediated immune responses. Contrary results were reported by Sujatha et al. (2013) who noted a non-significant difference between the mean hemagglutination-inhibition antibody titer and anti-mercaptoethanol resistant antibodies titer between the control group and the group fed with $200 \mathrm{~g}$ fresh Azolla/chick/day from 45 to 60 weeks in Nicobari fowls. Moreover, the haemagglutinating and immunoglobulin $\mathrm{M}$ responses to $1 \%$ chicken red blood cells were comparatively better in the choice-feeding group compared to the 5\% Azolla-fed group. In turkeys, Bhattacharyya et al. (2016) also reported that antibody response to sheep red blood cells was positively affected by $5.5 \%$ Azolla pinnata replacement in the conventional ration.

\section{CONCLUSION}

It can be concluded that Azolla species can be used as a source of protein and other essential nutrient elements for poultry species. Further research is required to determine the effects of using Azolla as a feed supplement in poultry ration.

\section{DECLARATIONS}

\section{Competing interests}

The author has no conflict of interest.

\section{REFERENCES}

Acharya P, Mohanty GP, Pradhan CR, Mishra SK, Beura NC and Moharana B (2015). Exploring the effects of inclusion of dietary fresh Azolla on the performance of White Pekin broiler ducks. Veterinary World, 8: 1293-1299. DOI: http://dx.doi.org.10.14202/vetworld.2015.1293-1299

Alalade OA and Iyayi EA (2006). Chemical composition and feeding value of Azolla (Azolla pinnata) meal for egg type chicks. International Journal of Poultry Science, 5: 137-141. DOI: http://dx.doi.org/10.3923/ijps.2006.137.141 
Alalade OA, Iyayi EA and Alalade TO (2007). The nutritive value of Azolla (Azolla pinnata) meal in diets for growing pullets and subsequent effect on laying performance. Journal of Poultry Science, 44: 273-277. DOI: https://doi.org/10.2141/jpsa.44.273

Ali MA and Leeson S (1995). The nutritive value of some indigenous Asian poultry feed ingredients. Animal Feed Science Technology, 55: 227-237. DOI: https://doi.org/10.1016/0377-8401(95)00801-S

Anitha KC, Rajeshwari YB, Prabhu TM, Patil MV, Shree JS and Anupkumar PK (2016a). Effect of supplementary feeding of Azolla on growth performance of broiler rabbits. ARPN Journal of Agricultural and Biological Science, 11: 30-36. Available at: http://www.arpnjournals.org/jabs/research_papers/rp_2016/jabs 01 $\underline{16 \text { 774.pdf }}$

Anitha KC, Rajeshwari YB, Prasanna SB and Shilpa SJ (2016b). Nutritive evaluation of Azolla as livestock feed. Journal of Experimental Biology and Agricultural Sciences, 4: 670-674. DOI: http://dx.doi.org/10.18006/2016.4(Issue6).670.674

Ara S and Adil S (2012). Impact of dietary inclusion of Azolla on production performance of broiler chicken. Geobios, 39: 236-240. Available at: https://researcherslinks.com/current-issues/Effect-ofAquatic-Fern-Azolla-cristata/20/1/1747/html

Ara S, Adil S and Khan MA (2018). Effect of aquatic fern, Azolla cristata in diet on growth, serum biochemistry and laying performance of chicken. Pakistan Journal of Zoology, 50: 23252329. http://dx.doi.org/10.17582/journal.pjz/2018.50.6.2325.2329

Ara S, Adil S, Banday MT and Khan M (2015). Feeding potential of aquatic fern-Azolla in broiler chicken ration. Journal of Poultry Science and Technology, 3: 15-19. Available at: https://www.semanticscholar.org/paper/Feeding-Potential-of-Aquatic-FernAzolla-in-Broiler-Ara-Adil/e9c9e0a4ea0101d24967c165d3acbb48fbc539bb

Ardakani MH, Shivazad M, Mehdizadeh SSM and Novrozian H (1996). Utilization of Azolla filliculoides in broiler nutrition. Journal of Agricultural Sciences, 2: 35-46. Available at: https://agris.fao.org/agris-search/search.do?recordID=IR9700792

Austic RE and Neshiem MC (1990). Poultry production, $13^{\text {th }}$ edition. Lea and Febiger, Philadelphia.

Bacerra M, Preston TR and Ogle B (1995). Effect of replacing whole boiled soya beans with Azolla in the diets of growing ducks. Livestock Research for Rural Development, 7: 1-11. Available at: http://www.lrrd.org/lrrd7/3/7.htm

Balaji K, Jalaludeen A, Richard CR, Peethambaran PA and Senthilkumar S (2009). Effect of dietary inclusion of Azolla (Azolla pinnata) on production performance of broiler chicken. Indian Journal of Poultry Science, 44: 195-198.

Balaji K, Jalaludeen A and Kannan A (2010). Effect of dietary Azolla on cholesterol content in broiler chicken. Indian Veterinary Journal, 87: 478-480.

Basak B, Pramanik MAH, Rahman MH, Tarafdar SU and Roy BC (2002). Azolla (Azolla pinnata) as a feed ingredient in broiler ration. International Journal of Poultry Science, 1: 29-34. DOI: http://dx.doi.org/10.3923/ijps.2002.29.34

Bastian CT (1987). Nutritive value of two species of aquatic ferns (Azolla microphylla Kaulfuss and Azolla pinnata R.Brown) in layer diets. College, Laguna, Philippines, p.53.

Becking JH (1979). Environmental requirements of Azolla for the use of tropical rice production. In: Nitrogen and rice. International Rice Research Institute, Los Banos, Laguna, Philippines, pp. 345374

Bested SB and Morento SE (1985). The effect of different percentage of Azolla on fattening pigs. Journal of Mountain State Agriculture Collage, 17: 31-40. Available at: https://agris.fao.org/agris$\underline{\text { search/search.do?recordID }=\text { PH8511419 }}$

Bhattacharyya A, Shukla PK, Roy D and Shukla M (2016). Effect of Azolla supplementation on growth, immuno-competence and carcass characteristics of commercial broilers. Journal of Animal
Research, 6: 941-945. DOI: https://doi.org/10.5958/2277940x.2016.00122.4

Bhuyan MAH, Hasanat MR, Ali MA and Rahman MA (1988). Effect of feeding Azolla (Azolla pinnata) on the performance of broiler. Bangladesh Journal of Animal Science, 27: 77-82. Available at: http://jakraya.com/journal/pdf/15-lriArticle 1.pdf

Biplob B, Ahsan HP, Muhammad SR, Sharif UT and Bimol CR (2002). Azolla (Azolla pinnata) as a feed ingredient in broiler ration. International Journal of Poultry Science, 1: 29-34. DOI:http://dx.doi.org/10.3923/ijps.2002.29.34

Buckingham KW, Stephen WE, James GM and Goldman CR (1978). Nutritive value of the nitrogen fixing aquatic fern Azolla filliculoides. Journal of Agricultural and Food Chemistry, 26: 12301234. DOI: https://doi.org/10.1021/jf60219a051

Castillo LS, Gerpacio AL and Pascual FSD (1981). Exploratory studies on Azolla and fermented rice hulls in broiler diets. College Laguna (Philippines), p. 6.

Cherryl DM, Prasad RMV, Rao SJ, Jayalaxmi P and Kumar DS (2014). A study on the nutritive value of Azolla pinnata. Livestock Research International, 2: 13-15. Available at: http://jakraya.com/journal/pdf/3-lriArticle_3.pdf

Das D, Sikdar K and Chetterjee AK (1994). Potential of Azolla pinnata as biogas generator and as a fish feed. Indian Journal of Environmental Health, 36: 186-191. Available at: https://www.cabdirect.org/cabdirect/abstract/19961300822

Dhumal MV, Siddiqui MF, Siddiqui MBA and Avari PE (2009). Performance of broilers fed on different levels of azolla meal. Indian Journal of Poultry Science, 44: 65-68. Available at: http://www.entomoljournal.com/archives/?year=2018\&vol=6\&issu e=4\&ArticleId $=3928$

Escobin RPJr (1987). Fresh Azolla (Azollamicrophylla kaulfuss) as partial replacement to palay-snail-shrimp based ration for laying mallard and growth-fattening Muscovy ducks. Thesis Submitted to Philippines University Los Banos, College, Laguna.

Henry ACE, Reetha TL, Paramasivam A and Mehala C (2017). Effect of Azolla supplementation on production performance of NandanamII turkey growers. Indian Veterinary Journal, 94: 28-30.

Hossiny H, Setoudeh M, Rokni H, Dehghanzadeh H and Cheraghcheshm M (2008). Using of silage Azolla in Guilan male calves nutrition. Proceedings of Third National Congress of Recycling and Reuse of Renewable

Organic Resources in Agriculture Islamic Azad University, Khorasgan Branch (Isfahan) Agricultural Faculty, Waste, and Water Research Centre. Available at: http://conference.khuisf.ac.ir/DorsaPax/userfiles/file/pazhohesh/cro wa1/79.pdf

Indira D, Sarjan RK, Suresh J, Venugopal NK and Ravi A (2009). Azolla (Azolla pinnata) as feed supplement in buffalo calves on growth performance. Indian Journal of Animal Nutrition, 26: 345-348. Available https://www.indianjournals.com/ijor.aspx?target=ijor:ijan\&volume $=26 \&$ issue $=4$ \&article $=009$

Islam MA and Nishibori M (2017). Use of multivitamin, acidifier and Azolla in the diet of broiler chickens. Asian-Australas Journal of Animal Science, 30: 683-689. DOI: https://dx.doi.org/10.5713\%2Fajas.16.0395

Ivan DT and Thuget TQ (1989). Use of Azolla in rice production in Vietnam. (In) Nitrogen and Rice, International Rice Research Institute, Philippines, p.395.

Kannaiyan S (1992). Azolla Biofertilizer Technology for Rice. Technical Pachyderm, Tamil Nadu Agricultural University, Coimbatore, Tamil Nadu, p.56. 
Kannaiyan S and Kumar K (2005). Azolla in animal feeding. In Azolla Biofertiliser for Sustainable Rice Production, Chapter 21, Daya Publishing House. Delhi.

Kathirvelan C, Banupriya S and Purushothaman MR (2015). Azolla- an alternate and sustainable feed for livestock. International Journal of Science, Environment and Technology, 4: 1153-1157. Available at: http://www.ijset.net/journal/748.pdf

Khatun A, Ali MA and Dingle LG (1999). Comparison of the nutritive value for laying hens of diets containing Azolla (Azolla pinnata) based on formulation using digestible protein and digestible amino acid versus total protein

and total amino acid. Animal Feed Science and Technology, 81: 43-56. DOI: https://doi.org/10.1016/s0377-8401(99)00071-1

Kumar M, Dhuria RK, Jain D, Sharma T, Nehra R and Prajapat UK (2018). Effect of feeding Azolla pinnata on the growth and performance of broiler chicks. International Journal of Chemical Studies, 6: 3284-3290. Available at: http://www.chemijournal.com/archives $/$ ?year $=2018 \&$ vol=6\&issue $=$ $3 \&$ ArticleId $=2900 \&$ si $=$

Lakshmanan A, Kumar K and Latha P (2017). Azolla - a low cost and effective feed supplement to poultry birds. International Journal of Current Microbiology and Applied Science, 6: 3622-3627. Available at: $\quad$ https://www.ijcmas.com/6-82017/A.\%20Lakshmanan,\%20et\%20al.pdf

Lakshmi V and Sailaja D (2012). Nutrient content of khoa samples prepared from Azolla and non - Azolla fed cow milk. International Journal of Biology, Pharmacy and Allied Sciences, 1: 364-369. Available at: https://www.academia.edu/38321255/AZOLLAEMERGING_ANIMAL_FEED

Lawas MVP, Roxas DB and Lambio AL (1998). Laying performance of Philippine Mallard ducks fed diets substituted with fresh Azolla. Recent developments in animal production - 1998: Proceedings of the Philippine Society of Animal Science $35^{\text {th }}$ Annual Convention, p. 220-225.

Lejeunea A, Cagauan A and Vanhove C (1999). Azolla research and development: recent trends and properties. Symbiosis, 27: 333-351. Available at: https://dalspace.library.dal.ca/bitstream/handle/10222/77695/VOLUME\%202 7-NUMBERS\%203\&4-1999-PAGE\%20333.pdf?sequence $=1$

Lejeune A, Peng J, Coulenge E, Larondella Y and Van Hove C (2000). Carotene content of Azolla and its variations during drying and storage treatments. Animal Feed Science and Technology, 84: 295301. DOI: https://doi.org/10.1016/s0377-8401(00)00129-2

Leterme P, Londono AM, Ordonez DC, Rosales A, Estrada F, Bindelle J and Buldegen A (2010). Nutritive value and intake of aquatic ferns (Azolla fillicoides Lam. and Salvinia molesta Mitchell) in sows. Animal Feed Science and Technology, 155: 55-64. DOI: https://doi.org/10.1016/j.anifeedsci.2009.10.002

Lumpkin TA (1984). Assessing the potential for Azolla use in the humid tropics. International Rice Commission News, 33: 30-33. Available at:https://agris.fao.org/agris-earch/search.do?recordID=XF8552445

Lumpkin TA and Plucknette DL (1982). Azolla as a green manure: use and management in crop production. Series No. 15, pp. 230, Westview Press, Boulder, Colorado, USA.

Mandal RN, Pandey BK, Chattopadhyay DN and Mukhopadhyay PK (2012). Azolla-an adequate form of significance to small scale. Aquaculture Asia, 18: 1. Available at: https://arccjournals.com/journal/bhartiya-krishi-anusandhanpatrika/BKAP36

Mathur GN, Sharma R and Choudhary PC (2013). Use of Azolla (Azolla pinnata) as cattle feed supplement. Journal of Krishi Vigyan, 2: 7375. Available at: http://iskv.in/wp-content/themes/iskv/volumepdfs/77c375b4c30658fe6bd13845afae0010jkv-2-1-018.pdf

Mishra DB, Roy D, Kumar V, Bhattacharyya A, Kumar M, Kushwaha R and Vaswani S (2016). Effect of feeding different levels of Azolla pinnata on blood biochemicals, hematology and immunocompetence traits of Chabro chicken. Veterinary World, 9: 192-198. DOI: https://dx.doi.org/10.14202\%2Fvetworld.2015.192$\underline{198}$

Mooventhan P, Kumar J, Dixit A, Sharma KC, Sivalingam PN, Gupta AK, Singh U, Singh SRK, Venkatesan P and Kaushal P (2019). Azolla: The super plant for sustainable feed production. Indian Farming, 69: 26-27. Available at https://www.nibsm.res.in/images/Azolla_The_super_plant_for_sust ainable feed production.Indian Farming.pdf

Muzlar AJ, Slinger SJ and Burton JH (1978). Chemical composition of aquatic macrophysics III. Mineral composition of fresh macrophysics and their potential for mineral nutrient removal from lake water. Canadian Journal of Plant Science, 58: 851-862. Available at: https://agris.fao.org/agrissearch/search.do?recordID $=$ CA7905100

Naghshi H, Khojasteh S and Jafari M (2014). Investigation of the effect of different levels of Azolla (Azolla pinnata) on performance and characteristics of Cobb broiler chicks. International Journal of Farming and Allied Science, 3: 45-49. Available at: https://www.semanticscholar.org/paper/Investigation-the-Effect-of-Different-Levels-of-(i-Naghshi-Khojasteh/5d533ebld26b0a7d19a7fc4767630cf35fe07357

Namra MMM, Hataba NA and Abdel Wahed M (2010). The productive performance of growing Fayoumi chicks fed restricted diets supplemented with free fresh Azolla. Egyptian Poultry Science Journal, 30: 747-762. Available at: https://www.ncbi.nlm.nih.gov/pmc/articles/PMC4774740/

Nwanna LC and Falaye AE (1997). Substitution of Azolla meal for groundnut cake in diets for Nile tilapia, Oreochromis niloticus (L). Applied Tropical Agriculture, 2: 139-143.

Pannaerker S (1988). Azolla as a livestock and poultry feed. Livestock Adviser, 13: 22-26. Available at: https://www.semanticscholar.org/paper/Feeding-Potential-of-Aquatic-FernAzolla-in-Broiler-Ara-Adil/e9c9e0a4ea0101d24967c165d3acbb48fbc539bb

Parashuramulu S, Swain PS and Nagalakshmi D (2013). Protein fractionation and in vitro digestibility of Azolla in ruminants. Online Journal of Animal Feed Research, 3: 129-132. Available at: http://www.ojafr.ir/main/attachments/article/95/Online\%20J.\%20A nim.\%20Feed\%20Res.\%203\%20(3)\%20129-132.pdf

Parthasarathy R, Kadirvel R and Kathaperumal V (2002). Azolla as a partial replacement for fishmeal in broiler rations. Indian Veterinary Journal, 79: 144-146.

Pillai PK, Premalatha S and Rajamony S (2005). Azolla: A Sustainable Feed for Livestock. LEISA Magazine, 21: 15-17. Available at: http://www.gemenskapspraktik.se/projects/theazollacookingandcult ivationproject/research/Azolla, $\% 20 \mathrm{a} \% 20$ sustainable\%20feed $\% 20 \mathrm{fo}$ r\%20livestock.pdf

Pillai PK, Premalatha S and Rajamony S (2002). Azolla - A sustainable feed substitute for livestock. LEISA India, 4:26-27. Available at: http://jakraya.com/journal/pdf/15-lriArticle_1.pdf

Prabina BJ and Kumar K (2010). Dried Azolla as a nutritionally rich cost effective and immuno-modulatory feed supplement for broilers. The Asian Journal of Animal Science, 5: 20-22. Available at: http://www.researchjournal.co.in/online/TAJAS/TAJAS\%205(1)/5 A-20-22.pdf

Querubin LJ, Alcantara PF and Princesa AO (1986). Chemical composition of three Azolla species (A. caroliniana, A. microphylla and A. pinnata) and feeding value of Azolla meal (A. microphylla) in broiler ration II. Philippine Agriculturist, 69: 479-490. Available at: search/search.do?recordID $=\mathrm{PH} 8810158$ https://agris.fao.org/agris-

Raja W, Rathaur P, John SA and Ramteke RW (2012). Azolla: an aquatic Pteridophyte with great potential. International Journal of Research in Biological Sciences, 2: 68-72. Available at: https://dofr.pw/feta cy cygub n.pdf 
Rana D, Katoch S, Mane BG, Rani D and Sankhyan V (2017). Biological Evaluation of Azolla in ration of commercial chicken broiler. Journal of Animal Research, 7: 601-607. DOI: http://dx.doi.org/10.5958/2277-940X.2017.00091.2

Rathod GR, Pramod T, Praveen T, Mandal AB and Shinde AS (2013). Feeding value of Azolla (Azolla pinnata) meal in growing Japanese quail. Indian Journal of Poultry Science, 48: 154-158. Available at: https://www.indianjournals.com/ijor.aspx?target=ijor:ijps\&volume $=48$ \&issue $=2$ \&article $=004$

Rawat N, Kumari K, Singh F and Gilhare VR (2015). Effect of Azolla supplemented feeding on milk production of cattle and production of broiler. Applied Biological Research, 17: 214-218. DOI: http://dx.doi.org/10.5958/0974-4517.2015.00031.2

Sadek MF, Fatma AG, Hanan AM, Hassanein M, Arafa M and Elham M (2010). Using of Azolla silage in growing rabbits feeding. Egyptian Journal of Rabbit Science, 20: 67-82.

Saikia N, Sapcota D and Hazarika R (2014). Effect of feeding Azolla (Azolla pinnata) meal to broilers: A field study in Assam. Indian Journal of Poultry Science, 49: 113-114. Available at: http://ijlr.org/issue/effect-of-feeding-of-azolla-azolla-pinnata-onthe-performance-of-white-pekin-laying-ducks/

Samad FAA, Idris LH, Abu Hassim H, Goh YM and Loh TC (2020). Effects of Azolla spp. as feed ingredient on the growth performance and nutrient digestibility of broiler chicken. Journal of Animal Physiology and Animal Nutrition, 00: 1-8. DOI: https://doi.org/10.1111/jpn.13345

Sarria P and Preston TR (1995). A chick assay method for the evaluation of non-conventional protein sources derived from Nacedero (Trichanthera gigantea) and Azolla (Azolla filiculoides). Livestock Research for Rural Development, 7: 6. Available at: http://www.lrrd.org//rrd7/3/6.htm

Senthilkumar S and Manivannam C (2016). Adoption of Azolla cultivation technology in the farmers field: An analysis. International Journal of Science and Environmental Technology, 5: 3081-3087. Available at: http://www.ijset.net/journal/1266.pdf

Seth N, Pradhan CR, Mishra SK, Pati PK and Panda SK (2013). Performance of Vanaraja chicken fed fresh Azolla as a protein substitute. M. V. Sc. Thesis submitted to Orissa University of Agriculture and Technology, Bhubaneswar.

Shamna TP, Peethambaran PA, Jalaludeen A, Joseph L and Aslam MKM (2013). Broiler characteristics of Japanese quails (Coturnix coturnix japonica) at different levels of diet substitution with Azolla pinnata. Animal Science Report, 7: 75-80. Available at: https://www.animalsciencereporter.com/7_2013_i2/75-80.pdf

Shukla M, Bhattacharyya A, Shukla PK, Roy D, Yadav B and Sirohi R (2018). Effect of Azolla feeding on the growth, feed conversion ratio, blood biochemical attributes and immune competence traits of growing turkeys. Veterinary World, 11: 459-463. DOI: https://doi.org/10.14202/vetworld.2018.459-463

Singh PK and Subudhi BPR (1978). Utilization of Azolla in poultry feed. Indian Farming, 27: 37-39.

Sood A, Uniyal PL, Prasanna R and Ahluwalia AS (2012). Phytoremediation potential of aquatic macrophyte, Azolla. Ambio, 41: 122-137. DOI: https://doi.org/10.1007/s13280-011-0159-z

Sreemannarayana O, Ramachamdraiah K, Sudarshan KM, Ramanaiah NV and Ramaprasad J (1993). Utilization of azolla as rabbit feed.
Indian Veterinary Journal, 70: 285-286. Available at: https://agris.fao.org/agris-search/search.do?recordID=IN9300569

Subudhi BPR and Singh PK (1978). Nutritive value of the water fern Azolla pinnata for chicks. Poultry Science, 57: 378-380. DOI: https://doi.org/10.3382/ps.0570378

Sudaryono A (2006). Use of Azolla (Azolla pinnata) meal as a substitute for defatted soybean meal in diets of juvenile black tiger shrimp (Penaeus monodon). Journal of Coastal Development, 9: 145-154. Available at: http://www.coastdev.undip.ac.id/

Sujatha T, Kundu A, Jeyakumar S and Kundu MS (2013) Azolla supplementation: Feed cost benefit in duck ration in Andaman Islands. Tamil Nadu Journal of Veterinary Animal Science, 9: 130136. Available at: http://www.tanuvas.ac.in/tnjvas/tnjvas/vol9(2)/130-136\%20pdf.pdf

Sundararaju V, Prabakaran R, Ahmed M, Abdul Mujeer K, Sundaravarathan S and Kannaiyan S (1995). Effect of feeding Azolla, Sesbania and Leucaena proteins on broiler performance. National workshop on Algal and Azolla biofretilizers, Tamil Nadu Agricultural University, Coimbatore, Tamil Nadu, p. 84.

Tamany Y, Samanta G, Chakraborty N and Mondal L (1992). Nutritive value of Azolla (Azolla Pinnata) and its potentiality of feeding in goats. Environment and Ecology, 10: 755-756. Available at: https://www.semanticscholar.org/paper/Chemical-composition-of-Azolla-(Azollapinnata)-and-Shinde-Prasade/6917ad146ba9fdc79b250c37fb5724c9bea7ad0e

Tyagi VVS, Mayne BC and Peters GA (1980). Purification and initial characterization of phycobiliproteins from the endophytic cyanobacterium of Azolla. Archives of Microbiology, 128: 41-44. DOI: $\underline{\text { https://doi.org/10.1007/BF00422303 }}$

Van Hove C (1989). Azolla and its multiple use with emphasis on Africa. Food and Agriculture Organization, Rome, 21: 112-116. Available at: https://agris.fao.org/agris-search/search.do?recordID=XF19910069349

Van Hove C and Lejeune A (1996). Does Azolla have any future in agriculture? In: Rahman M, Podder AK, Van Hove C, Znt B, Heulin $\mathrm{T}$ and Hartmann A, editors. Biological Nitrogen Fixation Associated with Rice Production. Kluwer Academic Publishers, Dordrecht. p. 83-94.

Varadharajan A, Gnanasekar R and Kothandaraman S (2019). Studies on feeding value of Azolla in quails in relationship to its carcass traits. The Pharma Innovation Journal, 8: 1143-1145. Available at: http://www.thepharmajournal.com/archives/2019/vol8issue4/PartR/ 8-4-124-734.pdf

Wagner GM (1997). Azolla: A review of its biology and utilization. The Botanical Review, 63: 1-26. Available at: https://www.jstor.org/stable/4354285

Wittouck P, Detimmerman F, Petry M and Van HC (1992). Azolla as a food for rabbit in Africa. Journal of Applied Rabbit Research, 5: 1058-1062. Available at: http://www.arpnjournals.org/jabs/research_papers/rp_2016/jabs_01 16_774.pdf

Yadav RKG, Abraham Y, Singh V and Singh PK (2014). Advancements in the utilization of Azolla-Anabaena system in relation to sustainable agricultural practices. Proceedings of the Indian National Science Academy, 80: 301-316. Available at: http://www.insaindia.org/journals/proceedings/Vol80_2014_2 Art1 $\underline{4 . p d f}$ 